\title{
THE EFFECT OF CREATIVITY TOWARD STUDENTS' ACHIEVEMENT IN WRITING ABILITY
}

\author{
Ning Setio Wati \\ Institut Agama Islam Negeri (IAIN) Metro, Lampung \\ E-mail: ningsetiowati87@gmail.com
}

\begin{abstract}
Writing is an activity to write and reformulate ideas to create meaning on a paper. In teaching writing, there are many influences, such as creativity. Creativity is an ability to create new product that can be useful and effective in original of thinking. This research is aimed at finding out whether creativity has significance influences toward writing achievement. The research was conducted at IAIN Metro in the academic year of 2012/2013. The population of this research was the third semester students of English Department of IAIN Metro. The result of this research is the students who have creativity could give significant effects on the students' writing ability and the creativity that was given by the lecturer was effective.
\end{abstract}

Keywords: Creativity, Students’'Achievement, Writing

\section{INTRODUCTION}

Teaching writing is one of productive skill in language skill. A productive skill is also called by active skills. It means that the skill can be practiced in daily activities. As mentioned by Golkova and Hubackova that productive skill is language skills that produced by users in spoken and written (Golkova \& Hubackova, 2014:478). Writing has an important role to express persons' feeling and ideas on a paper. In writing process, they can practice grammar structures, develop their vocabulary, and try to use punctuation in effective way. Those elements will be used in different way from passive skills, such as listening and reading skills.

Writing is an important skill to express the ideas in written text. Writing in second language is not easy of how to write something on paper. It is supported by Zainudin (2004:117) in O'Maggio, White and Arndt (1991) state that writing is not a simple matter of transcribing language into written symbols. In line with Ying (2018:118) English writing ability is a fundamental parts of one's English competence, but writing is still regarded as the most difficult task among the language skills, such as: listening, speaking, reading and translating because they do not know how to express their ideas in English. Thus, the most students feel frustrated by writing process. They lose interest in writing in English. Meanwhile, teachers also find the confusing of teaching writing because of students' have low motivation to write in good performance.

In fact, teachers often accuse that the students still fail to make improvement in their writing ability. The students still have large mistakes, such as: luck of vocabularies, unclear ideas, lack of logic connections between paragraphs, and grammatical errors. On the contrary, they feel that they still need to improve their writing abilities efficiently. Normally, In teaching writing process teachers pay more attention to give the 
feedback on writing result of the students but not in the writing process. Consequently, the teaching model does not lead the guidence in students' writing process.

Furthermore, writing process include some steps. Sharp (2016:77) in Lacina \& Silva (2011) states that writing process has sequence such as: planning, drafting, revising, editing and publishing during the acts of writing. Meanwhile, Tompkins (1994:118) devides the process of writing into three stages, such as: pre-writing, composing, and post-writing. The process of writing can helps the students to focus on the process of creating text through the various stages. However, the writer should know how to organaize their ideas in writing process. In fact, many writers still feel confused to write their ideas in first time to write. Thus, writing have process that include various stages to create the text.

Besides, the sequence of writing process will be influenced by some factors for having good writing. One of the factors is creativity. Creativity has part of writing process. It plays to produce a good under stable in writing. Grainger, at al (2005:13) state that creativity will influence of writing process in making choices about how to create ideas, choose vocabulary, arrange structure, and language. Creativity becomes important for the writers to organize their ideas in good manner. However, the writers can solve the problem in the difficult of writing. Thus, creativity is a process that involves in writing process to have good writing.

Every students is more or less creative in writing. As a concept Tung (2015:657) in Vein, et all defines creativity is an intercation among attitude, process, and environment by a person to produces a product that is both novel and useful as defined within a social context. Creativity means that the creation of a new product, service, idea, process aviable by individual in a complex social system. Moreover, Ozlem (2016:60) in Richard (2013) states that creativity is the ability to solve problems in original and valuable ways that are relevant to goals that have original and imaginative thoughts and ideas about something to create new learning possibilities. Students who have creativity can break down a problem easily in learning process. Therefore, Eva (2014:8) states that creativity has important role in education, because educational systems support creativity as relevant competence for the $21^{\text {st }}$ century.

Meanwhile, creativity in writing process has four teachable skill that cultivate creativity in writing process, such as: (1) fluency, (2) flexibility, (3) originality, (4) Elaboration. (Fredericks, 2005: 53). Fluency is one of skills to produce large number of creating ideas to think in writing process. It has role to arrange words to be sentences, and sentences to be paragraph in foreign language. As defined by Alisaari and Heikkola (2017: 273) Written fluency is ability to produce language in written text or text's length at normal speed without interruptions. Meanwhile, flexibility can be defined as the ability to make connections between unreleated concepts in insightful ideas (Pei, Zheng, Zhang, and Liu, 2017:39). Moreover, originality is the ability to make unique ideas in writing process. Then, elaboration is the ability to manipulate an idea until it is well formed (Fredericks, 2005: 53).

Therefore, creativity has a part of writing process. How the writers start to generate the ideas till the writers publish the text. It will be influenced by the creativity of the writers. However, the aim of the study was to know whether creativity could give significant effects on the students' writing 
and to know whether the creativity that was given by the teacher was effective or not.

\section{METHOD}

This research is descriptive quantitative design which used quasi-experimental. Sugiyono (2011:114) states that quasiexperimental is to establish cause-effect relationship between two or more variables. Meanwhile, this research is aimed at discovering the relationship between creativity and students' writing achievement through the use of correlation statistics.

The population in this research is all the third semester students of English Department at IAIN Metro in the academic year of 2012/2013 which consists of five classes, those are A, B, C, D, and E. The total number of the population in this research is 200 students who are divided into 8 classes. Meanwhile, the writer decided to take only 80 students or two classes from all of population as the sample of this study. The sample in this study was chosen randomly from the population of cluster which is usually called cluster random sampling. It means that all the members of cluster must be included in the sample.

Furthermore, there were two instruments used in this research; writing test and creativity test. The first instrument, a writing test, was constructed to investigate students' writing skill. Then, the second instrument, creativity test, was constructed to classify students in to different creativity level: students' high creativity, and students' low creativity.

The writing test was in the form of essay writing test. The test will be administered due to a limited time, 90 minutes. In this research, an essay writing test was a teacher's made test which was constructed to achieve objectives of writing skill being tested. The syllabus for Writing
III employed in English Department IAIN Metro focused on making an outline and expressing meaning in written functional text by the increasing of their ability in simple essay in the form of texts.

Besides, to make sure the test was appropriate for the skill measured, the writer assessed the readability of the test instruction which informs whether the test instructions were appropriately readable for the students. It means that if the test is tested to some students out of the sample group, they understand the instructions of the test and do as the instruction asks them to do. In other words, the instruction of the writing test should be clear and easy to be understood. It is essential that the writer obtains feedback to check that the test instructions have been received and understood. The success is the extent to which they understand it, read it at an optimum speed, and find it interesting. Before the test was used in this research, it was tried out to 45 students.

In order to know the students' creativity, the students were given the creativity test of Torrance Test of Creative Thinking (TTCT). The Torrance Tests of Creative Thinking (TTCT) is a test of creativity, originally involved simple tests of divergent thinking and other problem-solving skills, which were scored on four scales: Fluency, Flexibility, Originality, and Elaboration (Munandar, 2009: 65). Torrance Test consists of two forms, namely verbal and figural forms; both associated with the creative process and include the type of different thinking. The Figural TTCT is thinking creatively with pictures which appropriate at all levels, kindergarten through adult. Then, the Verbal TTCT is thinking creatively with words use six word-based exercises to assess three mental characteristics: Fluency, Flexibility, and Originality. 
In this research, the writer used the verbal TTCT to know the students' creativity. The tests were adapted from Munandar Creativity and Education (1992). The researcher decided to adapt the creativity test was due to the appropriateness of the content, easier calculation, and practicability. The kinds of the tests consist of Word Beginnings, Anagram, Three-WordSentences, Thing Categories, Unusual Use, and Consequences. Because of the tests were included of the productive skill, they were assessed by using readability of the test instruction which informs whether the test instructions were appropriately readable for students.

\section{RESULT AND DISCUSSION}

The test can be conducted after the result of the pretest is no significant difference between the treatment group and the control group. The result of the pretest shows that the score of the avarage creativity between the treatment class and control class are 67 and 65 . The results show that the creativity level for two groups is the same level. After conducting the pretest, the researcher conducted the treatment. Then, the data from the posttest were analyzed by comparing the mean score between the treatment class and the control class.

Effectiveness of the creativity enhance writing skill among the third semester students of English Departmen IAIN Metro. A $t$-test was used to determine if there were significant differences between the treatment and control class. It was tested for the treatment class among 40 students and 40 students for the control class. It shows that creativity has enhance the writing skill.

Forthemore, the researcher also compared the students' achievment based on creativity indicator by using one way ANOVA. Finding the difference in mean score of the writing achievement based on creativity indicator shows there are significant differences in writing achievement after the treatment given. Table.1 shows the result of t-test on the writing achievement based on creativity in fluency.

Table.1.Comparison of Achievement Between Treatment and Control Class For Creativity In Fluency

\begin{tabular}{cccccc}
\hline Group & $\mathrm{n}$ & Mean & $\begin{array}{c}\text { Standard } \\
\text { Deviasi } \\
(\mathrm{SD})\end{array}$ & $\mathrm{t}$ & $\begin{array}{c}\text { Significance } \\
\text { Value }\end{array}$ \\
\hline Treatment & 40 & 77 & 9.18 & 6.57 & .000 \\
\hline Control & 40 & 64 & 8.23 & & \\
\hline
\end{tabular}

Table 1 shows that the achievement mean score for the treatment class is 77 that has Standard Deviasi score 9.18. Meanwhile, the control class has mean score 64 with Standard Deviasi score 8.23. It means that the mean score of the treatment class is higher than the control class. Therefore, there is a significant difference in creativity in fluency between the treatment class and the control class.

Table.2.Comparison of Achievement Between Treatment and Control Class For Creativity In Flexibility

\begin{tabular}{cccccc}
\hline Group & $\mathrm{n}$ & Mean & $\begin{array}{c}\text { Standard } \\
\text { Deviasi } \\
(\mathrm{SD})\end{array}$ & $\mathrm{t}$ & $\begin{array}{c}\text { Significance } \\
\text { Value }\end{array}$ \\
\hline Treatment & 40 & 73 & 7.89 & 7.70 & .000 \\
\hline Control & 40 & 61 & 5.99 & & \\
\hline
\end{tabular}

Table 2 shows that the post test achievement mean score fore the creativity in flexibility for the treatment class that has 40 respondens is $73(\mathrm{SD}=7.89)$. Besides, the control class has the mean score 61 with the Standard Deviasi 5.99. The difference mean score between both of the calsses is 12 . Hence, the treatment class has significantly achieved higher inference score than the control classwith the value $t=7.70$ and the significance value $=.000<0.05$. It can show that the null hypotesis $\left(\mathrm{H}_{2}\right)$ is rejected. Therefore, between the treatment class and 
the control class have a significant difference creativity in flexibility.

Table.3. Comparison of Achievement Between Treatment and Control Class For Creativity In Originality

\begin{tabular}{cccccc}
\hline Group & $\mathrm{n}$ & Mean & $\begin{array}{c}\text { Standard } \\
\text { Deviasi } \\
\text { (SD) }\end{array}$ & $\mathrm{t}$ & $\begin{array}{c}\text { Significance } \\
\text { Value }\end{array}$ \\
\hline Treatment & 40 & 75 & 4.44 & 2.38 & .020 \\
\hline Control & 40 & 73 & 4.27 & & \\
\hline
\end{tabular}

Table 3 shows that post test achievement mean score for creativity in originality for the treatment class $75(\mathrm{SD}=4.44)$, while that for the control class is lower achievement 73 $(\mathrm{SD}=4.27)$. The difference in mean score between the treatment and control class is 2 . It means that both of the classes have the difference in mean score, but the score is not significantly high. In addition, the significance value is $.020<.05$. The finding shows that the null hypotesis $\left(\mathrm{H}_{3}\right)$ is rejected. Therefor there is a difference in creativity in originality between treatment class and control class.

Table.4. Comparison of Achievement Between Treatment and Control Class For Creativity In Elaboration

\begin{tabular}{cccccc}
\hline Group & $\mathrm{n}$ & Mean & $\begin{array}{c}\text { Standard } \\
\text { Deviasi } \\
(\mathrm{SD})\end{array}$ & $\mathrm{t}$ & $\begin{array}{c}\text { Significance } \\
\text { Value }\end{array}$ \\
\hline Treatment & 40 & 82 & 3.74 & 5.05 & .000 \\
\hline Control & 40 & 78 & 3.31 & & \\
\hline
\end{tabular}

Table 4 shows that the post test achievement mean score for the creativity in elaboration for the treatment class that has 40 respondens is $82(\mathrm{SD}=3.74)$. Besides, the control class has the mean score 78 with the Standard Deviasi 3.31. The difference mean score between both of the calsses is 4 . Hence, the treatment class has significantly achieved higher inference score than the control class with the value $t=5.05$ and the significance value $=.000<0.05$. It can show that the null hypotesis $\left(\mathrm{H}_{4}\right)$ is rejected. Therefore, between the treatment class and the control class have a significant difference creativity in elaboration.

Moreover, after finding on the difference in mean score of the achievement test based on the creativity indicator show that there is significant difference in student achievment after the treatment given. we also compared the students' achievement based on creativity indicator by using one way ANOVA. Table 5 shows the result of ANOVA on the students' achievement based on creativity indicator.

Table 5. One way ANOVA Achievement Test Marks Treatment Group Based on Creativity Indicator

\begin{tabular}{ccccc}
\hline & df & Mean Square & F & Sig \\
\hline $\begin{array}{c}\text { Between } \\
\text { Group }\end{array}$ & 3 & 239.27 & 3.63 & 0.01 \\
$\begin{array}{l}\text { Within } \\
\text { Group }\end{array}$ & 156 & 65.82 & & \\
\hline Total & 159 & & & \\
\hline
\end{tabular}

Based on the table 5 above, it can be indicated that there is significant difference in students' achivement based on creativity indicator. In one way ANOVA was uded to investigate the null hyphothesis. The table 5 shown that the mean between group for pst test is 239.27 and the mean within group is 65.82 with the test $F$ (3.63). Then, the significance has score (0.01). $0.01<0.05$. In another words, among 4 creativity indicators have significant difference in students' achivement in the treatment group post. Hence the null hypotesis is rejected.

Furhermore, we can analyze the the data to know the effective of creativity in writing achievement. The data can be analyzed by using multifactor analysis of Variance (ANOVA) 2X2. $\mathrm{H}_{\mathrm{o}}$ is rejected if $\mathrm{F}_{\mathrm{o}}$ is higher than $F_{t}\left(F_{o}>F_{t}\right)$. The test can be conducted after the result of normality and homogeneity tests are calculated. The $2 \times 2$ ANOVA and Tukey test are listed as follows: 
Table 6. Summary of a 2x2 Multifactor Analysis of Variance

\begin{tabular}{lccccc}
\hline \multicolumn{1}{c}{ Source of variance } & SS & df & MS & $\mathrm{F}_{\mathrm{o}}$ & $\mathrm{F}_{\mathrm{t}(05)}$ \\
\hline $\begin{array}{l}\text { Between rows (Students' } \\
\text { Crativity) }\end{array}$ & 1767 & 1 & 1767 & 43,26 & 3.97 \\
\hline
\end{tabular}

Based on the table 6 , we can analyze that $F_{o}$ (43.26) is higher than $F_{t}$ at the level of significance $\alpha=0.05$ (3.97), $\mathrm{H}_{\mathrm{o}}$ is rejected and the difference between rows is significant. It can be concluded that students having high creativity differ significantly from those having low creativity. In addition, the mean score of students who have high creativity (74) is higher than that of those who have low creativity (65). It can be concluded that the students having high creativity have better writing ability than those who have low creativity.

\section{CONCLUSION}

This paper has examined the effectiveness of creativity toward students' achievment in writing ability among the students of English Department in IAIN Metro. In addition, this paper also described the indicators of creativity among students by employing the The Torrance Tests of Creative Thinking (TTCT). It was found that all the indicator in null hypotheses were rejected because there were significant differences in creativity achievement between the group and the control group. ANOVA analysis of the treatment group also showed that there were significant differences in student achievement based on creativity indicators. Therefore, creativity based learning was effective in fostering writing ability among students of English Department in IAIN Metro. It indicates that the creativity was implemented successfully in writing ability. The outcome of this study will hopefully enhance the process of teaching and learning writing and enhance creativity among students.

\section{REFERENCES}

Fredericks, A. D. (2005). The complete idiot's guide to success as a teacher. New York, NY: Alpha.

Galkova, Dita, \& Hubackova, Sarka. (2014). Productive skills in second language learning. Procedia - Social and Behavioral Sciences 143 ( 2014 ) 477 - 481. ELSEVIER.

Grainger, Teresa, et al. (2005). Creativity and Writing: Developing Voice and Verve in the Classroom. New York: Routledge Taylor \& Francis Group.

Heikkola, Leena Maria, \& Alisaari, Jenni. (2016). Increasing fluency in L2 writing with singing. Studies in Second Language Learning and Teaching Journal. Department of English Studies, Faculty of Pedagogy and Fine Arts, Adam Mickiewicz University, Kalisz.

Munandar, Sukarni Catur Utami. (1992). Creativity and Education: Jakarta: Proyek Penggandaan/Penerjemah Buku direktorat Pembinaan Penelitian dan Pengembangan Pada masyarakat Direktorat Jendral Pendidikan Tinggi Departmen Pendidikan dan Kebudayaan.

O’Maggio, A. (1936). Teaching Lunguage in Context. Boston: Heinle \& Heinle.

Pei, Zhengwei, Zhang, Chaqom, et.all. (2017). Critical Thinking and Argumentative Writing: Inspecting the Association among EFL Learners in China. English Language Teaching; Vol. 10, No. 10; ISSN 1916-4742 E-ISSN 1916-4750. 
Canadian Center of Science and Education.

Sharp, Laurie. A. (2016). Acts of Writing: A Compilation of Six Models that Define the Processes of Writing. International Journal of Instruction. Vol.9, No.2. eISSN: 1308-1470 • $\underline{\text { www.e-iji.net. }}$.

Sugiyono. 2011. Metode Penelitian Kuantitatif, Kualitatif dan $R \& D$. Bandung: Afabeta.

Tompkins, G. E. (1994). Teaching Writing: Balancing Process and Product. NY:Merrill.

Trnova, Eva. (2014). IBSE and Creativity Development. Science Education International. Vol. 25, Issue 1. International Council of Assosiation for Science Education.

Tung, Chan Kwang. ( 2015). Assessment of Creative Writing: The Case of Singapore Secondary Chinese Language Curriculum. Universal Journal of Educational Research 3(10): 655-662. DOI: 10.13189/ujer.2015.031001.

Yagcioglu, Ozlem. (2016). Increasing Creativity With The Self-Studies In Basic English Classes. European Journal of English Language Teaching. Vol.1, No.2. I-SSN: 25017136.

Ying, Zhang. (2018). Exploring Construction of College English Writing Course from the Perspective of OutputDriven Hypothesis. English Language Teaching Journal. Voll1. No.2. ISSN 1916-4742 E-ISSN 1916-4750.
Zainudin, Mochamed. (2004). The Effect of Giving Feedback to Students' Writing. TEFLIN Journal. Vol. 15, No.2.
Canadian Center of Science and Education 